\title{
A Research Study on Beijing Fitness Club's Consumer's Satisfaction and Need of the Health Service
}

\author{
Xiao-Peng $\mathrm{CHI}^{1, a}$, Yue $\mathrm{YU}^{2, b,{ }^{*}}$, Qi CHEN ${ }^{3, c}$ \\ ${ }^{1}$ Dept. of Physical Education of Beijing Foreign Studies Univ., Beijing, P.R.C \\ ${ }^{2}$ Dept. of Physical Education of Univ. of International Business and Economics, Beijing, P.R.C \\ ${ }^{3}$ Dept. of Physical Education of Univ. of International Business and Economics, Beijing, P.R.C \\ ${ }^{a}$ sdp618@163.com \\ ${ }^{*}$ Corresponding author
}

Keywords: Fitness club, Customers, Health service, Satisfaction degree, Need.

\begin{abstract}
We studied on the service of 10 health clubs and requirement from 439 customers through questionnaire survey and interview, the results told us: 1) For the current health service, $75.7 \%$ of customers think they are of an average level. The longer customers being in a gem house, the less satisfied they feel with the group exercise. 2) Most customers prefer to have personal coach, in-time suggestion and feedback to the opinions of customers, to make customers feel being paid close attention. Things of these three aspects are wanted and desired most among customers. 3) The longer customers stay in a health club, the more they require in their course arrangement. 4) 85.9\% among customers are still willing to join in the health club if the expense and service quality are both promoted.
\end{abstract}

\section{Introduction}

With the development of society and the enhancement of people's health awareness, health club has become one of the main places of public health spending. As one of typical services, fitness club offers as intangible products as all the other services do; the service standard is one of the most critical factors affecting customer satisfaction, but also a basic principle in measuring competitiveness of a service enterprise. Whether club provides good or bad quality of health services for the consumer, and whether it can meet consumers' demand, is undoubtedly the key to sustainable development of health club.

Therefore, research on the health services of fitness clubs and analysis of consumers' satisfaction and demand in terms of fitness clubs' health services, make it effective and scientific for health clubs to improve the quality of health services, thus providing better health services to attract consumers, improve themselves in the competition and achieve sustainable development of overall health and fitness industry. In the meanwhile, the mass of consumers can enjoy a more comprehensive health services in the process of health spending, which is of great practical importance in promoting the public health.

\section{Methods of Study}

(1) Expert interview: Interviews were made with several old members and 13 senior managers from 10 health clubs, such as Bally, Bodyworks, Hosa so as to have a preliminary understanding of the health services provided by health clubs and the demand from consumers. Questionnaires have been assessed and amended several times by club executives and experts in related fields. Expert validity is good.

(2)Questionnaire: Used the compiled version of Beijing health club Health Services Survey Questionnaire to conduct research with 10 health clubs in Beijing, which are divided into large, medium and small at different levels, reflecting the status of Beijing's fitness club. In each health club, 40-60 randomly selected consumers accepted questionnaires. 460 questionnaires were distributed, and 439 valid questionnaires were recovered. The rate of valid recovery is $95.4 \%$, of 
which 208 were male, 231 female.

(3) Mathematical Statistics: Used SPSS11.0 statistical software for data analysis.

\section{Results and Analysis}

\section{Basic characteristics of health clubs' consumers}

The survey on factors affecting consumers to choose different clubs shows that the factors in descending order of importance are: Convenient location, reasonable price, comfortable environment, good service attitude, skilled coaches, hot phenomenon, content-rich courses, highend fitness equipment, convenient transportation, good advertising, good value-added services, and good ancillary facilities.

The survey on the consumers' purposes of participating in the club shows that three main purposes are to improve health, reduce fat, and keep fit.

The survey on favorite group courses shows that the top three courses appealing to consumers are "Spinning", "Yoga" and "Aerobics".

\section{The current conditions of the club's overall satisfaction with health services from consumers}

We studied on the service and overall satisfaction, the result told us: For the current health service, $75.7 \%$ of customers thought they were of an average level. Only 19.6\% of customers thought they were high level, and $4.7 \%$ thought the service satisfaction was low.

We studied on nine dimensions of health club services satisfaction, the result told us: the nine dimensions of health club services satisfaction in descending order are: reception, group courses coaches, equipment coaches, the whole atmosphere, fitness equipment, spinning, group exercise room class, value-added services, ancillary facilities.

\section{Comparative analysis of different groups of consumers of health services to the satisfaction of the club}

We have conducted $\mathrm{T}$ tests on nine dimensions satisfaction scores of health services from consumers of different genders, and the results are in Table 1:

Table 1 nine dimensions satisfaction scores of health services from consumers and the results of T tests

\begin{tabular}{|c|c|c|c|c|}
\hline dimensions & $\begin{array}{c}\text { male } \\
\text { average }\end{array}$ & $\begin{array}{c}\text { female } \\
\text { average }\end{array}$ & $\mathrm{T}$ & $\mathrm{P}$ \\
\hline reception & 3.85 & 3.98 & -2.209 & $0.028^{*}$ \\
\hline $\begin{array}{c}\text { equipment } \\
\text { coaches }\end{array}$ & 3.69 & 3.83 & -2.476 & $0.014^{*}$ \\
\hline
\end{tabular}

Note: $* * \mathrm{P}<0.01, * \mathrm{P}<0.05$, hereinafter the same

As is shown in the table 1 , both men and women have the highest scores in the foreground satisfaction and satisfaction with ancillary facilities is at the lowest score. Men' scores on the fitness equipment, group classes exercise room, indoor cycling, ancillary facilities, the overall atmosphere and value-added services dimension are higher than women's. Women in the foreground, instruments coach, and on a group lesson coach dimension score higher than men on a group lesson coach dimension. And women on the front, instrument instructor satisfaction score significantly higher than males $(\mathrm{P}<0.05, \mathrm{P}<0.05)$.

\section{Characteristics of demands from consumers for club health service}

We studied on six dimensions of demand level from the consumers for the club health services, the results told us that the six dimensions in descending order are: coaches, interpersonal communication, theoretical lectures, continued spending motivation, service facilities, lesson plans, 
among which consumers have the highest demand for coaches.

We studied on the level of consumer demand for health services in the club's six dimensions of 28 questions, the results told us: the research for six dimensions of 28 questions shows that three specific questions of consumer demand related to the two dimensions, of which the coach dimension "always having a special coach to guide" were the highest level of demand. Interpersonal communication dimension "to give timely feedback on consumer opinion" and "to make the consumer feel being concerned about" were the level of demand in second and three. The lowest level of consumer demand three specific questions related to the two dimensions of items, of which lesson plans dimension to "provide a single professional dance training course" was the lowest level of demand. Besides, the lower two questions of satisfaction are: continued spending motivation dimension "organization performances", race team, and lesson plans dimensions "providing professional beauty services".

\section{Comparative analysis of different groups of consumer demand for health services for the club}

Taking into account the different gender, age, education level, length of time involved in fitness and other groups may have different characteristics in terms of club health service needs. And for the club targeted to meet their needs, the study was carried out differences between each variable and each dimension of analysis, the following results:

We studied on needs of the consumers involved in the club at different times of the six dimensions of health services for the club scoring through ANOVA analysis of variance, results in Table 2:

Table 2 the result of needs of the consumers involved in the club at different times of the six dimensions of health services for the club scoring through ANOVA analysis of variance

\begin{tabular}{|c|c|c|c|c|c|c|c|c|}
\hline dimensions & $\begin{array}{c}\text { less } \\
\text { thana } \\
\text { month } \\
\text { on } \\
\text { average }\end{array}$ & $\begin{array}{c}\text { one to } \\
\text { three } \\
\text { months } \\
\text { on } \\
\text { average }\end{array}$ & $\begin{array}{c}\text { three } \\
\text { tosix } \\
\text { months } \\
\text { on } \\
\text { average }\end{array}$ & $\begin{array}{c}\text { six } \\
\text { months } \\
\text { toa } \\
\text { year on } \\
\text { average }\end{array}$ & $\begin{array}{c}\text { one } \\
\text { tothree- } \\
\text { year on } \\
\text { average }\end{array}$ & $\begin{array}{c}\text { more } \\
\text { thanthree- } \\
\text { year on } \\
\text { average }\end{array}$ & $\mathrm{F}$ & $\mathrm{P}$ \\
\hline lesson plan & 3.62 & 3.74 & 3.64 & 3.55 & 3.96 & 3.80 & 3.374 & $0.003^{* *}$ \\
\hline $\begin{array}{c}\text { motivation } \\
\text { of } \\
\text { continued } \\
\text { spending }\end{array}$ & 3.76 & 3.89 & 3.68 & 3.64 & 3.93 & 3.66 & 2.503 & $0.030^{*}$ \\
\hline
\end{tabular}

As is shown in Table 3, there is a significant difference $(\mathrm{P}<0.05)$ in the level of demand for spendingmotivation between consumers who participated in the clubs during different time. There is a very significant difference $(\mathrm{P}<0.01)$ in the curriculum plan needs dimension.

We made a further comparison on curriculum plans and continued spending motivation demand dimension between consumers who involved in the club with different spending time. The result is in the curriculum plan dimension, the demand of the consumers who have joined the clubs one to three years is significantly or very significantly higher than those who have joined the clubs less than one year $(\mathrm{P}<0.05, \mathrm{P}<0.01, \mathrm{P}<0.01)$. The demand of the consumers who have joined the clubs three to six months is significantly or very significantly higher than those who have joined the clubs six months to one year $(\mathrm{P}<0.05)$.

In the continued spending motivation dimension, the demand of the consumers who have joined the clubs one to three months is significantly higher than those who have joined the clubs three months to one year $(\mathrm{P}<0.05)$. The demand of the consumers who have joined the clubs one to three years is significantly higher than those who have joined the clubs three to six months and six months to a year $(\mathrm{P}<0.05, \mathrm{P}<0.01)$. 
Gender, age, educational level consumer groups, health services for the club six dimensions were no differences in the level of demand. It shows that the factors of sex, age, education level is unrelated to the demand on the health service and its various aspects. Needs are basically the same.

\section{Possibility analysis of the continued consumer spending when the clubs improve the quality and raise the prices}

We studied on the continued willingness to participate in club from the overall consumer consumption after the club improves the health service quality. The results are in Table 4:

Table 3 the results of possibility analysis of the continue consumer spending when the clubs improve the quality and raise the prices

\begin{tabular}{|l|c|c|c|c|c|c|}
\hline $\begin{array}{l}\text { Clubs enhance their own quality } \\
\text { of health service, and graduallyto } \\
\text { meet your needs, but the }\end{array}$ & \multicolumn{2}{|c|}{ YES } & \multicolumn{2}{|c|}{ [NO] } & \multicolumn{2}{|c|}{$\begin{array}{l}\text { [NOT } \\
\text { CERTAIN] }\end{array}$} \\
\cline { 2 - 8 } $\begin{array}{l}\text { pricewillenhance } \\
\text { thecorrespondingamplitude, if } \\
\begin{array}{l}\text { youwillcontinue to participate } \\
\text { inthe clubspending. }\end{array}\end{array}$ & $\begin{array}{c}\text { num } \\
\text { ber }\end{array}$ & $\begin{array}{c}\text { percentage } \\
(\%)\end{array}$ & $\begin{array}{c}\text { num } \\
\text { ber }\end{array}$ & $\begin{array}{c}\text { percentage } \\
(\%)\end{array}$ & $\begin{array}{c}\text { num } \\
\text { ber }\end{array}$ & $\begin{array}{c}\text { percentag } \\
\text { e(\%) }\end{array}$ \\
\cline { 2 - 8 } & 377 & 85.9 & 45 & 10.3 & 17 & 3.9 \\
\hline
\end{tabular}

As is shown in the table 3 , under the situation where clubs enhance their own quality of health service and gradually to meet consumers' needs, with the price enhancing the corresponding amplitude, 377 consumers still will participate in the clubs, accounting for $85.9 \%$ of those surveyed. 45 consumers won't participate in the clubs, accounting for $10.3 \%$ of those surveyed. 17 consumers chose the answer "not certain", accounting for 3.9\% of those surveyed. It shows that most consumers are willing to pay higher price for the better health service offered by the clubs.

\section{Conclusions and Suggestions}

\section{Conclusions}

(1) The top three purposes for consumption in the clubs are to improve health, reduce fat, and keep fitness and the top three favorite courses from consumers are "Spinning", "Yoga" and "Aerobics".

(2) For the current health service, $75.7 \%$ of customers thought they were of an average level. The nine dimensions of health club services satisfaction in descending order are: reception, group courses coaches, equipment coaches, the whole atmosphere, fitness equipment, spinning, group exercise room class, value-added services, and ancillary facilities. The satisfaction in the group class exercise room dimensions from the consumers who joined the club less than half a year significantly higher than these who joined the club more than half a year. $75.6 \%$ of customers have satisfaction with the club personal trainer services at a higher degree.

(3)The demands on the six dimensions of health club services from consumers are in descending order: coaches, interpersonal communication, theoretical lectures, continued spending motivation, facilities, curriculum plans. Three specific questions of consumer demand related to the two dimensions, of which the coach dimension "always having a special coach to guide" were the highest level of demand. Interpersonal communication dimension "to give timely feedback on consumer opinion" and "to make the consumer feel being concerned about" were the level of demand in second and three. The lowest level of consumer demand three specific questions related to the two dimensions of items, of which lesson plans dimension to "provide a single professional dance training course" was the lowest level of demand. Besides, the lower two questions of satisfaction are: continued spending motivation dimension "organization performances, race team" and lesson plans dimensions "providing professional beauty services ".

(4) $85.9 \%$ of consumers were still willing to continue to participate in the club spending, when the health clubs improved the quality of service and raised the price. 


\section{Suggestions}

(1)Clubs should focus on improving internal ancillary facilities(shower, toilet, dressing, etc.), increase the investment to the value-added services. Front desk service personnel and equipment coaches can strengthen the concern on the male consumers and increase the proportion of female equipment coaches. Strengthen publicity to personal trainer, particularly the role of private coach in fat loss and shaping aspect, to attract more women to choose private services.

(2)Although the health clubs have increased the training in the aspect of raising the professional level of coaching, literacy, etc., but the coach services was still the most demanded aspect by consumers. The clubs still need to improve the level of coaching, and the addition of a variety of coaching services, as much as possible to maintain a stable coaching team, do not easily replace coach. Most consumers' purpose to consumer in the club were trying to keep fit and reduce fat through fashion fitness way. They demanded less for health club professional dance, performance team, and beauty. The clubs don't have to concentrate on these services.

(3)Clubs can adjust the price, while clubs improved the quality of services, additional services, and increased the investment. This will not cause too much impact on consumers' willingness to spend.

\section{References}

[1] Zhu dangpei, Zhang wenzhong.Rational thinkingon the establishment ofa newrural community health club issues [J]. Sports and Science, 2006.27. (3).

[2] Liu Xueyong. Experience Economy - Fitness club's future development patterns [J]. Beijing Sports University, 2006.29(8).

[3] Li Xiaofen. Development features and business model of China's commercial health club [J]. Shanghai University of Sport, 2006.30(3).

[4] Li Xiaofen, Li Chunlei. Application research in the diamond positioning model bluebird fitness club market position [J]. Beijing Sports University, 2006.29(5).

[5] Xiao Shuhong. China sports club value chain management status and the coping measures [J]. Beijing Sports University, 2005.28(4).

[6] Chen Aimin, Yu weiping. Shenzhen fitness club status and development proposals [J]. Journal of Physical Education, 2006.13(4). 